REVISTA INTERNACIONAL DE CIENCIAS DEL DEPORTE International Journal of Sport Science

doi:10.5232/ricyde2009.01702

Rev. int. cienc. deporte

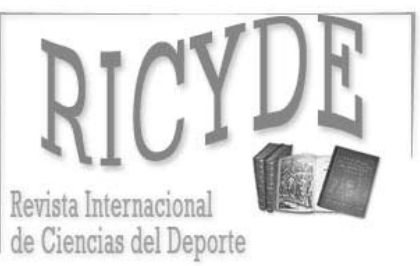

International Journal of Sport Science VOLUMEN V - AÑO V

Páginas:19-32 ISSN:1885-3137

No 17 - Octubre - 2009

\title{
Development of Expertise in Spanish Elite Basketball Coaches. El desarrollo de la pericia en los entrenadores españoles expertos en baloncesto.
}

\author{
Sergio Jiménez Sáiz \\ Facultad de Ciencias de la Actividad Física y del Deporte. Universidad Europea de Madrid \\ Alberto Lorenzo Calvo \\ Facultad de Ciencias de la Actividad Física y del Deporte-INEF. Universidad Politécnica de Madrid \\ Sergio J. Ibáñez Godoy \\ Facultad de Ciencias del Deporte, Universidad de Extremadura
}

\begin{abstract}
Resumen
The present study was designed to address two issues: first, to identify the different development stages that eight expert Spanish basketball coaches go through; and second, to determine the possible factors that have contributed to the formative or training, process of the expert coach. Qualitative data were gathered in semi-structured interviews. The coaches worked with the men's first Spanish Basketball League ("ACB" league) or the Spanish national selection. Our findings reveal four stages in the coach development process. These stages were the consequence mainly of a gradual progression in thinking and reflective practice that enabled the coach to optimize the necessary skills for high performance. In addition, all the coaches interviewed reflected an intense dedication and commitment over many years to their work, as well as an ongoing quest for improvement.
\end{abstract}

Key words: development; stages; expertise; basketball coaches.

\begin{abstract}
El presente estudio fue diseñado para hacer frente a dos cuestiones: en primer lugar, identificar las diferentes etapas formativas de ocho entrenadores expertos en baloncesto, y en segundo lugar, determinar los posibles factores que han contribuido a la formación del entrenador experto. La metodología utilizada es la cualitativa y la técnica de recogida de datos fue la entrevista semiestructurada. Los entrenadores entrevistados pertenecían a la liga ACB o a la selección nacional española. Nuestros resultados ponen de manifiesto cuatro etapas en el desarrollo de su pericia. Estas etapas son consecuencia principalmente de un desarrollo de su conocimiento, así como de una profunda reflexión práctica que permitió al entrenador optimizar las habilidades necesarias para trabajar en el alto rendimiento. Además, todos los entrenadores reflejan una intensa dedicación y compromiso durante muchos años hacia su trabajo, así como una búsqueda constante por mejorar.
\end{abstract}

Palabras clave: formación; estadios; pericia; entrenadores de baloncesto. 
$\mathrm{T}$ he term expertise generally refers to the mechanisms that underlie and lead to the achievements of experts. An expert is defined as an individual who has attained a high performance level in any field of work and is the product, amongst other things, of the individual's training, intense practice activity and an appropriate social environment (Csikszentmihalyi, 1996; Ericsson \& Lehmann, 1996; Housner \& French, 1994). The performance of the expert has been described as the final outcome of a gradual improvement in performance during a prolonged period of experience in a specific area (Richman, Gobet, Staszewski, \& Simon, 1996). Schempp, McCullick, and Mason (2006, 155) stated that expert coaches:

... Are able to coach more athletes to higher levels of success in a greater variety of environments in a shorter amount of time... This does not mean that an expert can necessarily coach every player to master every skill under any circumstances, but rather on an overall basis, the athletes of expert coaches learn more and perform better than athletes of less expert coaches.

Many studies centering on the professional development of the coach have highlighted the importance of the training received and how the coach's career path was analyzed (Abraham, Collins, \& Martindale, 2006; Bloom, Salmela, \& Schinke, 1995; Jones, Armour, \& Potrac, 2003; Jones, Armour, \& Potrac, 2004; Salmela, 1995). These studies have also identified a need for further research undertaken from a biographic perspective targeted at establishing how certain factors could affect the process of becoming an expert (Gilbert, Côté, \& Mallett, 2006).

In these reports, several stages in the coach formative process are identified (Bell, 1997; Berliner, 1994; Jones, et al., 2004; McCullick, Cumings, \& DeMarco, 1998; Salmela, Draper, \& Desjardins, 1994; Salmela, 1995; Schempp, et al., 2006). The work of Schempp, et al. (2006), for example, defines the four stages: i) beginner, ii) competent, iii) proficient, and iv) expert. By definition, beginner coaches were those with less than three years of professional experience, and were more concerned about student behavior than about transmitting knowledge. With experience, the coaches started to develop skills that allowed them to minimize the time spent on non-coaching tasks, leaving them more time to improve player performance. Coaching competence was described as the stage when a coach used previous experience to solve a new experience or situation. Once a considerable amount of knowledge and experience had been acquired, the proficient coach was able to distinguish important from unimportant issues, they responded using less rational thought and more instinct and intuition, and finally, they felt a strong personal responsibility for the successes and failures of their athletes. In the last, or expert, stage, the main distinguishing feature of the coach was his intuition and automaticity in decision-making.

Schinke, Bloom, and Salmela (1995) examined the progression of six expert Canadian basketball coaches, from their first athletic experience to their present coaching positions. Their results revealed seven chronological career stages: early sports participation, elite sport, international elite sport, novice coaching, developmental coaching, national elite coaching and international elite coaching. When their athletic careers came to an end, the coaches searched for possible ways to remain affiliated to the sport. The novice and developmental coaching levels reflected a search for an appropriate coaching philosophy and new skills. Concurrently, the developmental coaches acquired theoretical and applied knowledge from academic institutions and mentor coaches. Due to their winning records, the coaches were all hired to work with university teams. The difference between national and international level coaches was minimal; those who became international level coaches made winning a priority. 
Woodman (1993) claimed that the key to improve coaching is related to the training of the coach himself. As confirmed in recent studies, coaches are gradually shaped by an exchange of information over years of instruction practice. Accordingly, the primary sources of knowledge construction were practical coaching experience and observing other coaches (Cushion, 2001; Gould, Gianinni, Krane, \& Hodge, 1990). There is agreement among coaches that learning from experience plays an important role in their development (Culver \& Trudel, 2006). Gould, et al. (1990) found that the most significant factors for the development of coaches were an informal education and knowledge acquired through experience. As suggested by Cushion, Armour, and Jones (2003), most of what a coach learns is via interaction with the coaching context as well as through informal sources.

However, improving performance is not thought to be an automatic consequence of experience gained and the simple exchange of opinions, but rather this improvement requires a particular type of experience. This experience is denoted "deliberate practice" (Ericsson, Krampe, \& Tesch-Römer, 1993) and defined as practice that is planned, highly structured and performed with an express desire for improvement. In general, the amount of deliberate practice has been linked to the performance level of experts of different fields such as music, mathematics and several sports (Ericsson, 1996).

Based on the different studies performed so far (Abraham, et al., 2006; Bloom, et al., 1995; Jones, et al., 2003), knowledge construction in coaches is achieved through means such as: i) formal and non-formal education (specific courses, sports clinics, seminars); ii) observing other expert coaches and information transfer among these; iii) coaching experience itself with the consequent reflection; iv) competition itself; and v) the existence of a mentor or some sort of structured mentoring program. The results of recent studies have also highlighted the relevance of previous experience as athletes, whether of the same sport or any other sports discipline (Côté, 2006; Gilbert, et al., 2006), or the importance of selfguided learning through specialized books, manuals, journal articles, videos, etc. (Nelson, Cushion, \& Potrac, 2006).

The role of mentors has been examined in several studies, whose conclusions indicate their key contribution to the development of coaches (Bloom, Durand-Bush, Schinke, \& Salmela, 1998; Cushion, et al., 2003; Irwin, Hanton, \& Kerwin, 2004; Moreno, Moreno, Iglesias, García, \& Del Villar, 2007; Salmela, Draper, \& Laplante, 1993). Cushion (2006, 131) adds that the mentoring that exists in this context is "unstructured, informal, and uneven in terms of quality and outcome, uncritical in style and, from the evidence, serves to reproduce the existing culture and power relations found in existing coaching practice".

Finally, these studies have also highlighted a desire for improvement on the part of the coach as an important attribute (Bloom \& Salmela, 2000). Thus, Jones, et al. (2003) indicated that the construction of professional knowledge was essentially the responsibility of the individual.

The present study was designed to address two issues: first, to identify the different development stages that expert Spanish basketball coaches go through; and second, to determine the possible factors that have contributed to the formative, or training, process of the expert coach. 


\section{Methods}

To dissect the development and training of expert basketball coaches, we used the qualitative approach, whose "main goal is to reduce the amount of data and obtain a unified picture of the phenomena under study" (Côté, Salmela, Baria, \& Russell, 1993, 130). Qualitative procedures have been widely used in sports science. Gilbert and Trudel (2004) reported that emphasis on quantitative research had shifted over time and that qualitative methods were being increasingly used.

\section{Population Sample}

Eight elite coaches who were experts in basketball were interviewed. All the coaches were male and held the highest-level basketball coach title possible in Spain. Their average experience of $28.9 \pm 2.58$ years included coaching teams playing in Spain's first professional men's basketball league (ACB league) and/or national teams.

According to Abraham, et al. (2006), a set of criteria needs to be established to assign a coach the "status" of expert. However, given the lack of a clear model for this purpose at present, we based our selection of expert coaches on the different standards defined in the literature (e.g., Côté, Salmela, Trudel, Baria, \& Russell, 1995; Horton, Baker, \& Deakin, 2005; Saury \& Durand, 1998). Thus, the coaches were required to satisfy the following: i) to be recognized as a prestigious coach in the world of professional basketball, so all the coaches interviewed were recommended by peers as good examples of "expert coaches" (Abraham, et al., 2006; Bloom \& Salmela, 2000; Schinke, et al., 1995); ii) to have won some professional basketball award with his team (Schinke, et al., 1995). In effect, all the coaches had won at least one important competition such as the world basketball championship, European championship or ACB league competitions; and iii) to have coached professional international teams and players (Salmela, 1995).

\section{Interview}

Data were obtained through a semi-structured detailed interview, a technique commonly used in qualitative analyses (Patton, 2002). A set of guidelines was used to outline the basic areas to be covered, although any new question arising during the interview was also analyzed in depth (Potrac, Jones, \& Armour, 2002). Rather than asking questions, this kind of interview resembled an ordinary conversation, with the participant doing most of the talking.

The interview was designed according to the following steps: i) first, interviews used in similar studies were reviewed (e.g., Bloom \& Salmela, 2000; Côté, et al., 1995; Schinke, et al., 1995); ii) a first draft of the interview was prepared; iii) a pilot interview was conducted; and iv) the final version of the interview was established. This final version was revised by a research team with experience in qualitative methods.

All the coaches were interviewed in private by a single interviewer. The mean interview time was 100 minutes. The interviewer, who was familiar with the game and had experience in working with elite level coaches, was trained through lectures, role-playing and two pilot interviews. General demographic information was obtained at the start of each interview (e.g., what qualifications do you have? or how did you become a basketball coach?) and then, through specific questions, the stages of each coach's formative process were explored.

\section{Data analysis}

All interviews were literally transcribed immediately after the completion of each interview as described by others (e.g., Bloom \& Salmela, 2000; Schinke, et al., 1995), and a copy given to each coach along with a summary of the interpretation made by the researchers, so that they 
could check their opinions had been correctly interpreted. This information was not collected for analysis but was used to redefine the categories described below.

The objective of our analysis was to build and organize a system of categories that could explain the formative process of the expert basketball coaches. In line with the works of Côté, et al. (1993) and Côté, Salmela, and Russell (1995), first of all an inductive approximation was made as three main steps: creating tags, creating properties and creating and conceptualizing categories.

The first step in a qualitative analysis is to divide the entire text into pieces of information known as meaning units (Côté, et al., 1993). A meaning unit is defined as a segment of text that expresses the same idea and is related to the same topic (Tesch, 1990). Each meaning unit was then named or "tagged" based on its content. Some of the tags describing the topics included mentors, learning from others or sharing information. Out of 927 meaning units identified, we focused on the data assigned to the category "development of expertise", which comprised 221 meaning units and 18 different tags.

In the second step of this type of data interpretation, similar tags are grouped together to give a series of properties (Côté, et al., 1993). We used an inductive approach to establish these properties, continuously revising the data until there was consensus in the properties identified. In this manner, the 18 tags were grouped as 2 properties ("training as a coach" and "career path").

The final level of classification consists of grouping similar properties into categories to give a lower number of higher-order categories. This step is similar to the previous stage of creating properties, except it is now done at a higher and more abstract level of analysis (Côté, et al., 1995). Thus, the 2 properties established were assigned to the single category "development of expertise". Table 1 provides the breakdown components of this category.

Table 1. Number of Tags and Meaning Units (MU) in each of the Two Properties

\begin{tabular}{|l|l|}
\hline PROPERTIES/TAGS & MU \\
\hline Career path & 79 \\
1. Reasons to start & 12 \\
2. Opportunities & 8 \\
3. Imitative practice & 18 \\
4. Reflective practice & 16 \\
5. Development knowledge & 13 \\
6. Expert & 5 \\
7. Reasons to continue & 7 \\
\hline Training as a coach & 142 \\
& \\
1. Own experience & 20 \\
2. Personal reflections & 18 \\
3. Experience as a players & 16 \\
4. Mentors & 16 \\
5. Relationship with their peers & 16 \\
6. Observing others coaches & 17 \\
7. Desire to learn & 15 \\
8. Own competition & 7 \\
9. Formal education & 17 \\
\hline
\end{tabular}

The reliability of the analysis was established by an independent expert familiar with the use of qualitative methods, who classified a random sample of the replies given by the coaches (15\% of the meaning units). After a period in which the classification system used was explained to the expert, the expert was instructed to place each meaning unit within a tag, 
property and category. Only the text of each meaning unit was analyzed and not the title of each unit. Agreement between this independent analysis and the research team's analysis was $97 \%$ for assigning the correct property to each meaning unit.

According to Sparkes (1998), monitoring by the interviewees is the best way to ensure credibility. Thus, the 8 participants were sent a summary of the results and were then requested to make any comments or changes they felt appropriate. Six of the coaches replied and we could say that their responses improved the reliability of the description of the coach development process.

\section{Results}

\section{Career path}

The mean time of experience as coaches was 28.9 years $( \pm 2.58)$, of which, a mean of 16.5 years $( \pm 6)$ had been spent as high performance level coaches (ACB league and national selections). Most of the coaches interviewed started their coaching activities around the age of 18 years. Many had already coached youth teams while practicing basketball. The reasons given by the coaches interviewed for starting basketball were varied. A passion for basketball and for teaching the sport were some of the reasons offered, along with factors such as an admiration for, or influence of, other coaches or persons, the tradition of a player continuing as coach, economic reasons, or keeping contact with friends or the basketball environment.

You are there, because you think you can help teach people, because you have a vocation. I think that the coach's vocation is not only the vocation of a coach it is also the vocation of a teacher (Subject 2, translated from Spanish).

According to our data, we could clearly distinguish four main stages in the development of expertise process. The first stage, "Imitative practice", is characterized by abandoning the game as a player and applying the experience gained as a former player to coaching young players. The training tactics and drills and exercises selected were not the most appropriate and in many cases involved repeating the drills and training exercises performed as players.

At that time I was totally imitative. Let's say to the extent of 100\%. I had no ideas or baggage to offer anything different to what I would do or to what they made me do (Subject 7, translated from Spanish).

This stage is also characterized by the coaches taking on roles in basketball other than coaching, such as referee, taking field notes, etc.

Also, at the same time as being players, we had to be referees, take field notes, whatever. We lived basketball in a thousand ways (Subject 8, translated from Spanish).

Passing onto the next stage coincided with leaving university or work to become full-time basketball coaches. All but two of the coaches interviewed decided to abandon their formal education as soon as they realized that their vocation, their ideal profession, was that of basketball coach.

And this was already my third year as coach. It was then that I left my studies to devote more time to basketball (Subject 4, translated from Spanish).

In the second or "Reflective practice" stage, the study coaches were influenced or mentored by other coaches, whom they helped or watched. In parallel, our coaches at this stage started to show intense basketball knowledge as the result of having attended courses, observed training sessions, lived through experiences, etc. These feats were complemented with the 
opportunity to act as first coach of a team or of youth ACB club teams obtaining good results. During this stage, a significant change occurs in the coach's perspective and a more critical position is adopted with respect to what they see or do themselves.

Bit by bit as you enter more in the career of coach, you also start to imitate, but this time not your coach, not the experiences you have had as a player, but the experiences you see in other coaches. I think this process is fairly important, because you don't only start to imitate, you also reflect on why you do this (Subject 4, translated from Spanish).

Access to the elite setting is often the result of the opportunity arising when a coach has been in an elite team for many years as coach assistant or as coach for the second team. Stage three -that of the "Development knowledge"- is characterized by the independence of the coach and is the consequence of a coaching opportunity or working with an elite basketball team. The coaches' knowledge of the sport is great due to many years of deliberate work and training, and they have a good capacity for leadership, teamwork and competition. During this stage they are completely autonomous, being capable of proposing new things and knowing what to do at a given moment in time.

I think you're ready because you are capable of creating your own systems, your own proposals, your attack, your defense, when you are capable of designing them... There you are at a high development level, but as you evolve from this level, you realize that what is really important is your capacity for making the team do what you want it to do, or that the team does the best it can to win (Subject 1, translated from Spanish).

At the fourth "expert coach" stage, the coach is considered capable of offering something to the specialty. The coaches interviewed here are presently at this stage, and contribute not only knowledge or an understanding of the sport but also to factors related to managing a group of athletes.

It's the stage of wisdom. To reach this stage you would have to know a lot about basketball. If the first is excitement, the second is self-criticism, the third is perspective, and the fourth stage is that of wise people (Subject 8, translated from Spanish).

Finally, we tried to determine why someone would wish to dedicate so much time to one activity and the reasons for doing so. A large variety of reasons for dedicating themselves to basketball coaching were given: i) an excitement and motivation for basketball, and especially for teaching young players; ii) having sports projects and goals and trying to achieve these goals; iii) the career itself (i.e., wishing to become a coach); iv) success or social and economic recognition; and v) entertainment or fun. Keeping up this sort of compromise was highly conditioned by: i) achieving sports success such as winning a championship, or non competitive success in activities such as coaching young players to reach the top level; and ii) both social and personal recognition.

\section{Training as a coach}

Overall, it was observed that the coaches interviewed felt that the best way to learn was from their own experience as a coach. Clearly, as mentioned above, in the formative stages of the coach, this experience should be reflective and critical. Besides highlighting the importance of this reflective experience, the coaches also valued a desire for constant improvement and progression such that they understood their development as a continuous process undertaken with an express will to improve. 
Afterwards, you also realize that the best training for being in high-level competition is being in high competition (Subject 1, translated from Spanish).

As any thing in life, I think that there is nothing without study, without study and without reflection, and with practice of course. It is like a circle or spiral. There has to be study, reflection, and practice and then you start again (Subject 2, translated from Spanish).

The coaches also valued their previous experience as players. All the coaches questioned had played basketball or another sport before coaching and some initially even coached and played at the same time.

If you study and immediately start coaching it's difficult. In contrast, if you have played its easier, since you have played and reflected, much has been gained, you analyze what you study with what you have played or with what you are doing and you start shaping the package (Subject 5, translated from Spanish).

Throughout the interviews several means of knowledge construction were outlined by the coaches. Each coach highlighted the existence of persons who throughout their professional development acted as mentors. As revealed by the coaches interviewed, this relationship with the mentor or mentors goes clearly beyond the mere transfer of knowledge. Our results indicate that this relationship has two components: a conceptual one that provides knowledge and a social or affectionate component.

The people who made me change my life, who made me dedicate myself to this, and who have told me that this is much more than playing, this is commitment, dedication, your colleagues... This has really changed my way of understanding life, what is fair or unfair... (Subject 6, translated from Spanish).

Another development means constantly mentioned by the coaches was their relationship with their peers. For instance, they considered as important, conversations with other coaches, or debates during trips or meetings on topics that had anything to do with basketball.

I have spent hours and hours in cafés talking about basketball and scribbling on bits of paper (Subject 2, translated from Spanish).

We could talk for days, they were unending conversations. We had to defend and argue our theories from the rest. This taught us much about any point and many hours of knowledge construction and reflection (Subject 6, translated from Spanish).

In this area of relationships with other coaches, the coaches analyzed also valued observing other coaches as an important factor for their formation, even coaches of other sports, or even being observed and then assessed by peer coaches.

You can always learn something, some detail, some phrase that you can apply to your game. I love going to watch the soccer or handball teams train. I think that you can grasp things from other team sports for my sport (Subject 8, translated from Spanish).

Other development methods mentioned by the coaches included attending official coaching courses, sports clinics or specific basketball meetings, although they also described their limited usefulness. The coaches also mentioned that it is very difficult to find time for more academic activities during the season. As a consequence of this, access to the specific literature is also considered an important formative means even if not related to basketball but to anything that can improve their work (physical fitness, psychology, etc.)

You find out what you need most and concentrate on this... At each moment and depending on the individual coach, this will mean focusing on one area or another but not because one is 
more important than another but because this is probably the one needed most (Subject 6, translated from Spanish).

\section{Discussion}

Our description of the path followed by coaches as four stages is consistent with the stages proposed in other studies (Bell, 1997; Jones, et al., 2004; McCullick, et al., 1998; Schempp, et al., 2006; Schinke, et al., 1995). This development process is driven by a change in the characteristics of coaches, their progress in decision-making, and in changes in their problemresolving ability, organizing knowledge and self-evaluation and reflection capacity.

During the first stage, the beginner coach relies upon the experience gained as a player, and requests of his players the same practical drills he was required to perform. This feature was pointed by Schinke, et al. (1995), who confirmed the importance of the experience a coach had as a basketball player. According to Penney (2006), a huge proportion of young people's learning experiences will be gained through their community of practice. Two factors enabled us to identify this influence. First, all the coaches interviewed started their career early on in life (Salmela, et al., 1993), and secondly, in the first few years of their coaching positions, most of them continued to play (Schinke, et al., 1995) or undertook other activities (e.g., worked as referee or assistant coach in a higher level team).

The importance of previous experience as a player has been underscored. Several studies (Bloom, 2002; Hardin, 2000; Irwin, et al., 2004; Sage, 1989; Schinke, et al., 1995) have reported that a common trait among expert coaches is the dedication of several thousands of hours to being athletes, even participating in several sports. This initial experience could be related to the subsequent level of competence reached as coaches, since this experience provides them with a good understanding of the game's tactics and role of the coach (Gilbert, et al., 2006). This experience also means that the coach knows how the players feel and think during training and competition sessions (Trudel, 2006) and also determines a capacity to demonstrate skills, maneuvers, etc. (Potrac, et al., 2002).

The second stage of the coach development process was described by Schinke, et al. (1995) and Schempp, et al. (2006), and involves the pursuit of greater knowledge through experience, mentor coaches and personal reflection. The third, or proficient, coach stage is the outcome of the number of hours invested, the level of compromise, and the experience and knowledge acquired (Schempp, et al., 2006). This knowledge allows the coach to respond to a given situation in an instinctive and intuitive way, to design his own training protocol and try out new ideas. The transition between one stage and the next is usually promoted by new responsibilities taken on when coaching at a more competitive level or because of a good opportunity. Schinke, et al. (1995) described that the culmination of the coach development process is a consequence of the opportunity that arises.

The fourth stage revealed by our results, that of the expert coach, fits in well with the final stage in the process of gaining expertise described by Ericsson, et al. (1993), who referred to an eminent expert. The coaches interviewed mentioned some of the characteristics pointed out by Schempp, et al. (2006), such as the great effort made to improve their training through the use of different sources (e.g., books, conversations with other coaches) or their improved capacity for self-criticism and in-depth reflection. Saury and Durand (1998) explained that the knowledge of an elite coach is acquired by redefining experience within a given context, and is highly personal and very difficult to explain. These authors accordingly described expert coaches as very open-minded on a day-to day basis. 
The last two stages we describe here, however, show several differences to those suggested by Schinke, et al. (1995). The stages defined by these authors depended on the competition level at which the coaches had developed their skills. In addition, whether they reached a given stage depended on their success, as well as on whether the coaches changed the focus of their practice, prioritizing results. Our results do not confirm this suggestion, and indicate that moving from one stage to the next one was determined by acquiring autonomy, an extensive knowledge or an intuitive ability (Schempp, et al., 2006).

This development of the capacity of a coach is a clear consequence of a strong commitment to both learning and the coach's career. Several studies (Bloom \& Salmela, 2000; Côté, 2006; Hardin, 2000; Schempp, et al., 2006) highlight this feature as a characteristic of expert coaches. Bloom and Salmela (2000) and Salmela (1996) reported that this commitment can be noted both at the family and personal levels.

In line with observations made in similar studies (Cushion, 2001; Gilbert \& Trudel, 2001; Gould, et al., 1990), experience seems to be an important source for the coach learning process. Although, the difference between a coach with experience and an expert coach is determined by how he analyses, rationalizes and critically reflects upon coaching. Experience is a prerequisite for developing expertise, but coaches need to learn from their experience to improve (Bell, 1997; DeMarco \& McCullick, 1997).

Our findings are consistent with those obtained by Irwin, et al. (2004), who describe the mentor as the most relevant development means. Gilbert and Trudel (2001) demonstrated that mentoring occurs in the coach-forming setting, although only in a destructured and informal manner. Salmela, et al. (1993) and Bloom, et al. (1998) concluded that the most important formative means for coaches were mentors, who widened their knowledge through observation. Much of what a new coach learns is through ongoing interactions in the practical coaching context, as well as a variety of informal sources (Cushion, 2006). According to Nelson, et al. (2006) and Culver and Trudel (2006), informal learning occurs via "communities of practice".

Similarly, the coaches interviewed here placed special emphasis on conversations with other coaches as an important part of their formative process. Gilbert and Trudel (2001) found that when coaches have the opportunity to discuss issues experienced in their work, those conversations or discussions were highly significant to them. Cassidy and Rossi (2006) reported that coaches perceive conversations with other coaches as very valuable for their professional development, even more so than formal training.

Finally, the results of this investigation reveal the difficulty coaches to have in accessing a more formal type of education. As mentioned by Gilbert, et al. (2006), given the demands of competition, the coaches found it impossible to attend any formal education program. As a consequence, they opted for self-learning to gain knowledge in the areas they considered basic for their coaching skills, using various sources (books, internet, and magazines).

\section{Conclusions}

According to Lyle (2002), the process of becoming a coach is complex, dynamic and dependent on the context, and as such requires a multidimensional approach to fully capture its essence and provide useful information. Our study revealed that the development of expertise in coaches goes hand in hand with experience, dedication, study and reflection, along with interactions among these factors. 
According to the replies of the coaches interviewed here, we were able to observe their gradual development through four well-differentiated stages. The knowledge gained by the coaches was acquired through experience, both as coaches and players, and through interpreting this experience. Apart from this experience, our coaches especially highlighted the importance of a mentor figure in their development process and indicated that their guidance went beyond the mere transfer of knowledge. Interaction with other coaches was also considered an important formative factor, either through observing or discussing issues with these or through non-formal education such as attending courses, clinics, etc. Finally, the coaches interviewed shared a common characteristic, that is, a desire to improve and continue learning throughout their life.

Acknowledgements

This study was partly funded by Project 16/UPB20/06 of the "Consejo Superior de Deportes, C.S.D." of the Spanish "Ministerio de Educación y Ciencia". The authors would like to thank the University of Extremadura and Politécnica de Madrid for their help in conducting this study. Finally, we thank all the coaches interviewed for their collaboration and their comments and contributions to this study.

\section{References}

Abraham, A., \& Collins, D. (1998). Examining and extending research in coach development. Quest, 50, 59-79.

Abraham, A.; Collins, D., \& Martindale, R. (2006). The coaching schematic: Validation through expert coach consensus. Journal of Sports Sciences, 24 (6), 549-564.

Bell, M. (1997). The Developmental of expertise. Journal of Physical Education, Recreation and Dance, 68 (2), 34-38.

Berliner, D.C. (1994). Expertise: The wonder of exemplary performances. In J.N. Mangieri \& C.C. Block (Eds.), Creating powerful thinking in teachers and students: Diverse perspectives (pp. 161-186). Fort Worth, TX: Holt, Reinhardt, \& Winston.

Bloom, G. A. (2002). Coaching demands and responsibilities of expert coaches. In J. M. Silva \& D. E. Stevens (Eeds.) Psychological Foundations of Sport (pp. 438-465). Boston, MA: Allyn and Bacon.

Bloom, G.A.; Durand-Bush, N.; Schinke, R.J., \& Salmela, J.H. (1998). The importance of mentoring in the development of coaches and athletes. International Journal of Sport Psychology, 29 (3), 267-281.

Bloom, G.A., \& Salmela, J.H. (2000). Personal characteristics of expert team sport coaches. Journal of Sport Pedagogy, 6 (2), 56-76.

Bloom, G.A.; Salmela, J. H., \& Schinke, R.J. (1995). Expert coaches views on the training of developing coaches. In R. Vanfraechem - Raway \& Y. Vandem Auweele (Eeds.), Proceedings of the 9th European Congress on Sport Psychology (pp. 401-408). Brussels, Belgium: Free University of Brussels.

Cassidy, T., \& Rossi, T. (2006). Situating Learning: (Re)examining the notion of apprenticeship in coach education. International Journal of Sports Sciences \& Coaching, 1 (3), 235-246.

Côté, J. (2006). The development of coaching knowledge. International Journal of Sports Sciences and Coaching, 1 (3), 217-222.

Côté, J. ; Salmela, J.H., \& Russell, S. (1995). The knowledge of high-performance gymnastic coaches: Methodological framework. The Sport Psychologist, 9, 65-75. 
Côté, J. ; Salmela, J.H. ; Baria, A., \& Russell, S. (1993). Organizing and interpreting unstructured qualitative data. The Sport Psychologist, 7, 127-137.

Côté, J.; Salmela, J.H.; Trudel, P.; Baria, A., \& Russell, S.J. (1995). The coaching model: A grounded assessment of expertise gymnastic coaches' knowledge. Journal of Sport \& Exercise Psychology, 17, 1-17.

Csikszenmihalyi, M. (1996). Creativity. Flow and the psychology of discovery and invention. New York: HarperCollins Publishers.

Culver, D.M., \& Trudel, P. (2006). Cultivating coaches' communities of practice. In R. Jones (Ed.) The Sports Coach as Educator: Re-concetualising sports coaching (pp. 97112). London: Routledge.

Cushion, C.J. (2001). Coaching research and coach education: Do the sum of the parts equal the whole? SportaPolis, September (on-line). Retrieved January 14, 2007, from http://www.sportsmedia.org/Sportapolisnewsletter4.htm

Cushion, C.J. (2006). Mentoring: Harnessing the power of experience. In R. Jones (Ed.) The Sports Coach as Educator: Re-concetualising sports coaching (pp. 129-144). London: Routledge.

Cushion, C.J.; Armour, K.M., \& Jones, R.L. (2003). Coach education and continuing professional development: Experience and Learning to coach. Quest, 55, 215-230.

DeMarco, G.M., \& McCullick, B. A. (1997). Developing expertise in coaching: Learning from the Legends. Journal of Physical Education, Recreation and Dance, 68 (3), 3741.

Ericsson, K.A. (1996). The road to excellence: The acquisition of expert performance in the arts and sciences sports and games. Hillsdale: Lawrence Erlbaum.

Ericsson, K. A.; Krampe, R., \& Tesch-Römer, C. (1993). The role of deliberate practice in the acquisition of expert performance. Phychological Review, 100 (3), 363-406.

Ericsson, K.A., \& Lehmann, A.C. (1996). Expert and exceptional performance: Evidence on maximal adaptations on task constraints. Annual Review of Psychology, 47, 273305.

Gilbert, W.D., \& Trudel, P. (2001). Learning to coach through experience: Reflection in model youth sport coaches. Journal of Teaching in Physical Education, 21, 16-34.

Gilbert, W.D., \& Trudel, P. (2004). Analysis of coaching science research published from 1970-2001. Research Quarterly for Exercise and Sport, 75 (4), 388-399.

Gilbert, W.D.; Côté, J., \& Mallett, C. (2006). Developmental paths and activities of successful sport coaches. International Journal of Sports Science and Coaching, 1 (1), 69-76.

Gould, D.; Gianinni, J.; Krane, V., \& Hodge, K. (1990). Educational needs of elite U.S. national Pan American and Olympic coaches. Journal of Teaching in Physical Education, 9, 322-344.

Hardin, B. (2000). Coaching expertise in high school athletics: Characteristics of expert high school coaches. Applied Research in Coaching and Athletics Annual, 15, 24-38.

Horton, S.; Baker, J., \& Deakin, J. (2005). Experts in action: A systematic observation of 5 national team coaches. International Journal of Sport Psychology, 36, 299-319.

Housner, L. D., \& French, K. E. (1994). Future directions for research on expertise in learning, performance, and instruction in sport and physical activity. Quest, 46, 241246.

Irwin, G.; Hanton, S., \& Kerwin, D.G. (2006). Reflective practice and the origin of elite coaching knowledge. Reflective Practice, 5 (3), 425-442. 
Jones, R.; Armour, K., \& Potrac, P. (2003). Constructing Expert Knowledge: A case study of a top-level professional soccer coach. Sport, Education and Society, 8 (2), 213229.

Jones, R.; Armour, K., \& Potrac, P. (2004). Sports Coaching Cultures. From practice to theory. London: Routledge.

Lyle, J. (2002). Sports coaching concepts: A framework for coaches' behaviour. London: Routledge.

McCullick, B.; Cumings, R., \& DeMarco, G.M. (1998). The road to expert coaching. Georgia Association for Health, Physical Education, Recreation and Dance Journal, 31 (1), 4249.

Moreno, M. P.; Moreno, A.; Iglesias, D.; García, L.; Del Villar, F. (2007). Effect of a mentoring through reflection program on the verbal behavior of beginner volleyball coaches: a case study. Revista Internacional de Ciencias del Deporte. 8(3), 12-24. Retrieved September 29, 2007, from http://www.cafyd.com/REVISTA/00802.pdf

Nelson, L.J.; Cushion, C.J., \& Potrac, P. (2006). Formal, nonformal and informal coach learning: A holistic conceptualisation. International Journal of Sports Sciences \& Coaching, 1 (3), 247-259.

Patton, M.Q. (2002). Qualitative evaluation and research methods ( $3^{\text {rd }}$ ed). Newbury Park. CA: Sage.

Penney, D. (2006) Coaching as teaching. In R. Jones (Ed.), The Sports Coach as Educator: Re-concetualising sports coaching (pp. 25-36). London: Routledge.

Potrac, P.; Jones, R., \& Armour, K. (2002). "It's all about getting respect": The coaching behaviours of an expert English soccer coach. Sport, Education and Society, 7, 183202.

Richman, H.B.; Gobet, F.; Staszewski, J.J., \& Simon, H.A. (1996). Perceptual and memory processes in the acquisition of expert performance: The EPAM model. IEn K.A. Ericsson (ed.), The Road to Excellence: The Acquisition of Expert Performance in the Arts and Sciences, Sports and Games (pp. 167-187). Hillsdale: Lawrence Erlbaum.

Sage, G (1989). Becoming a high school coach: From playing sports to coaching. Research Quarterly for Exercise and Sport, 66, 81-92.

Salmela, J. H. (1995). Learning from the development of expert coaches. Coaching and Sport Science Journal, 2 (2), 3-13.

Salmela, J.H. (1996). Great Job Coach: Getting the edge from proven winners. Ottawa, Ontario: Potentium, the Coaching Network.

Salmela, J.H.; Draper, S.P., \& Desjardins, G. (1994). Transitional phases of expert ice and field hockey coaches' careers. In: Commonwealth Conference in Sport Science, Access to active Living (pp. 570-575). Victoria, Canada: University of Victoria PressAccess to Active Living (pp. 570-575). Victoria: University of Victoria.

Salmela, J.H.; Draper, S.P., \& Laplante, D. (1993). Development of expert coaches of team sports. In S. Serpa, J. Alves, V. Ferreira, \& A. Paula - Brito (eds.) Proceedings 8th World Congress of Sport Physichology. Sport Physichology: an integrated approach. ISSP.SPPD (pp. 296-300). Lisboa: FMH-UTL.

Saury, J., \& Durand, M. (1998). Practical knowledge in expert coaches: On site study of coaching in sailing. Research Quarterly for Exercise and Sport, 69, 254 - 266.

Schempp, P.G.; McCullick, B., \& Mason, I.S. (2006). The development of expert coaching. In R. Jones (Ed.), The Sports Coach as Educator: Re-concetualising sports coaching (pp. 145-161). London: Routledge. 
Schinke, R.J.; Bloom, G.A., \& Salmela, J.H. (1995). The evolution of elite Canadian basketball coaches. Avante, 1, 48-62.

Sparkes, A.C. (1998). Validity in qualitative inquiry and the problem of criteria: implications for sport psychology. The Sport Psychologist, 12, 363-386

Tesch, R. (1990). Qualitative research analysis types and software tools. New York: Falmer Press.

Trudel, P. (2006). What the coaching science literature has to say about the roles of coaches in the development of elite athletes. International Journal of Sports Sciences \& Coaching, 1 (2), 127-130.

Woodman, L. (1993). Coaching: A science, an art, an emerging profession. Sport science Review, 2 (2), 1-13. 